\title{
Protist
}

April 2019, Volume 170, Issue 2, Pages 168-186

https://doi.org/10.1016/i.protis.2019.02.003

https://archimer.ifremer.fr/doc/00483/59496/

\section{Discovery of a New Clade Nested Within the Genus Alexandrium (Dinophyceae): Morpho-molecular Characterization of Centrodinium punctatum (Cleve) F.J.R. Taylor}

\author{
Li Zhun ${ }^{1}$, Mertens Kenneth ${ }^{2}$, Nézan Elisabeth ${ }^{2}$, Chomérat Nicolas ${ }^{2}$, Bilien Gwenael ${ }^{2}$,
} Iwataki Mitsunori ${ }^{3}$, Shin Hyeon Ho ${ }^{1, *}$

${ }^{1}$ Library of Marine Samples, Korea Institute of Ocean Science and Technology, Geoje, Republic of

Korea

2 Ifremer, LER BO, Station de Biologie Marine,Place de la Croix, BP40537, F-29185 Concarneau

Cedex, France

${ }^{3}$ Asian Natural Environmental Science Center, The University of Tokyo, Bunkyo, Tokyo, Japan

* Corresponding author : Hyeon Ho Shin, email address : $\underline{\text { shh961121@kiost.ac.kr }}$

\begin{abstract}
:
Investigation of phytoplankton from East China Sea of the Pacific Ocean, offshore Réunion Island of the Indian Ocean, and the French Atlantic coast revealed a species of poorly known armored fusiform dinoflagellate. To clarify this species, morphology and phylogeny based on mitochondrial and nuclear protein gene sequence (Cox1, Cob and Hsp90) concatenated with the SSU, ITS region and LSU rDNA sequences were analysed. Epifluorescence and scanning electron microscopy observations revealed that the nucleus of the specimen was elongated, sausage-shaped and located equatorially on the left lateral side of the cell, and that the plate formula is Po, 3', 1a, 6", 6C, 8S, 5'", 1p, 2"'. These morphological features indicate that the species can be assigned to Centrodinium punctatum. Interestingly, the phylogenetic analyses placed this species within the Alexandrium clade, with Alexandrium affine being its closest relative. This indicates that genus Alexandrium is not monophyletic. The most similar morphological traits between $C$. punctatum and Alexandrium species were the shape of apical pore plate and the arrangement of the sulcal plates. However, since there are significant morphological differences between C. punctatum and Alexandrium species, further studies are needed to clarify the relation between the morphology and molecular phylogeny of other Centrodinium-related fusiform species.
\end{abstract}

Keywords : Fusiform dinoflagellate, Centrodinium, Alexandrium, morphology, phylogeny 


\section{Introduction}

Dinoflagellates are a large group of protists (estimated 2,377 species) that are ubiquitous in marine environments (Gómez 2012; Taylor 1987). They are commonly divided into armored and unarmored forms (e.g., Dodge 1982; Fensome et al. 1993; Kofoid and Swezy 1921). The armored dinoflagellates 
possess a series of relatively rigid thecal plates and their classification is primarily based on the number and arrangement of the thecal plates (e.g., Fensome et al. 1993; Taylor 1976) and is largely corroborated by molecular phylogeny (e.g., Janouškovec et al. 2017; Saldarriaga et al. 2001). However, the classification based on the morphological characters of some species is sometimes incongruent with the phylogenetic position inferred from ribosomal DNA (rDNA) sequencing data, creating uncertainty about the taxonomic status of the targeted species.

Over the past twenty years, detailed evaluations of morphology combined with molecular phylogenetic studies of dinoflagellates have resulted in descriptions of new species and re-classification of existing species (e.g., Daugbjerg et al. 2000; Hoppenrath et al. 2009; John et al. 2014; Li et al. 2015 2017). In particular, highly conserved molecular markers such as ribosomal DNA (rDNA) are most informative for the resolution of relationships between terminal nodes in phylogenetic trees (Hoppenrath 2017). Recently, in addition to rDNA gene sequencing, the use of mitochondrial and nuclear protein genes, such as cytochrome c oxidase I (Cox1), cytochrome b (Cob) and heat shock protein 90 (Hsp90), have clarified the relationships between morphological characters and the phylogenetic placement of dinoflagellates (e.g., Hoppenrath and Leander 2010; Lin et al. 2009).

Among marine armored dinoflagellates, some species characterized by a unique fusiform shape are gonyaulacoid, and belong a.o. to the genera Centrodinium Kofoid, Gonyaulax Diesing, Pavillardinium de Toni, Schuettiella Balech and Spiraulax Kofoid (e.g., Balech 1962; Carbonell-Moore 1996; HernándezBecerril et al. 2010; Taylor 1976). Armored fusiform dinoflagellates have rarely been reported, and their morphology and distribution are poorly known. As a consequence, the taxonomic status of the fusiform dinoflagellates has been continuously revised (e.g., Carbonell-Moore 1996; Hernández-Becerril et al. 2010; Kofoid 1907; Sournia 1986), and molecular data have not been obtained, except for the cyst-based taxon Dapsilidinium pastielsii (Davey \& Williams) Bujak, Downie, Eaton \& Williams (Mertens et al. 2014).

One of the armored fusiform dinoflagellate genera, the genus Centrodinium Kofoid, was erected in 
1907, with Centrodinium elongatum Kofoid as the type species (Kofoid 1907), but no thecal plate formula was given in the original description. The genus Centrodinium strongly resembles some species previously assigned to Pavillardinium [e.g., P. punctatum (Cleve) de Toni], and for this reason, Taylor (1976) transferred five Centrodinium-like Pavillardinium species to the genus Centrodinium. The genus Pavillardinium was erected to replace the genus Murrayella Kofoid by de Toni (1936), because the genus Murrayella was already preoccupied by the red algal genus Murrayella Schmitz (Kofoid 1907; Schmitz 1893). Currently, 18 species are assigned to the genus Centrodinium which includes some previously recorded Murrayella and Pavillardinium species (Guiry and Guiry 2018). Most Centrodinium species are distributed in tropical to temperate regions, e.g., the north-eastern Atlantic Ocean (Okolodkov and Dodge 1997), the Indian Ocean (Taylor 1976), and the Mexican Pacific coast (Hernández-Becerril et al. 2010). However, despite such records on the distribution of Centrodinium species, morphological observations of many Centrodinium species, including its type, are incomplete and accordingly, the classification of Centrodinium is currently unclear and remains untested with molecular phylogenetic data.

During a study of field samples from the East China Sea with the purpose to document the diversity of marine dinoflagellates, a poorly known armored fusiform dinoflagellate was encountered, and a culture was successfully established. With the aim to identify this fusiform dinoflagellate, this culture was examined by light and scanning electron microscopy, and the small subunit (SSU) rDNA, internal transcribed spacer 1 (ITS1) and ITS2, 5.8S rDNA, partial large subunit (LSU) rDNA and nuclear protein gene sequence (Cox1, Cob and Hsp90) were sequenced. The aim was to understand how this species compared to Centrodinium punctatum (Cleve) Taylor and its relation to other gonyaulacoid genera such as Alexandrium. In addition, the SSU rDNA sequencing data were compared to sequences of two morphologically similar specimen obtained from the French Atlantic coast.

\section{Results}


On the basis of the morphological and molecular results presented herein (Figs 1-10; Appendix S1), the present species is identified as Centrodinium punctatum, and the SSU, ITS region, LSU, Cox1, Cob and Hsp90 gene sequences of this species were deposited in GenBank (Appendix S2).

\section{Morphology of Centrodinium punctatum}

Living cells were solitary, broadly fusiform and yellow in color (Fig. 1A-F). The cells were 40.7-80.6 $\mu \mathrm{m}$ (average $=62.4 \mu \mathrm{m}, n=50)$ in length, $19.5-40.9 \mu \mathrm{m}$ (average $=31.2 \mu \mathrm{m}, n=50)$ in width, and 21.4-39.9 $\mu \mathrm{m}$ (average $=29.7 \mu \mathrm{m}, n=50$ ) in depth (dorso-ventral axis), with an average width-to-depth ratio of $\sim 1.1$. The epitheca was prolonged in an apical horn, $\sim 43 \%$ of the total length of the body, measured from the proximal end of the cingulum. The hypotheca also extended into a horn and it was longer than the epitheca, $\sim 54 \%$ of the total length of the body, measured from the distal end of the cingulum. The cingulum descended by about one cingulum width (Fig. 1A). The sulcus was not broader than the cingulum. The thecal surface was strongly areolated, which was visible under a light microscope (Fig. 1A, C, F). One or two pusules were visible in the cell (Fig. 1B, E). Cells contained numerous chloroplasts (Fig. 1G, H). The nucleus was elongated, sausage-shaped and located on the left- lateral side of the cell (Fig. 1G, H).

The thecal morphology of Centrodinium punctatum collected from East China Sea and offshore Réunion Island, Indian Ocean is shown in Figures 2-8. The cells displayed a plate formula of Po, 3', 1a, 6", 6C, 8S, 5"', 1p, 2'"' (Figs 2-8). The typical plate pattern is illustrated in Figure 8. The epitheca was composed of the apical pore plate (Po), three apical plates ( $\left.3^{\prime}\right)$, one anterior intercalary plate (1a), and six precingular plates $\left(6^{\prime \prime}\right)$ (Figs 2, 3, 7). The Po plate was slightly sunken and enclosed by the surrounding plates and located centrally at the apex (Figs 3B, D, 7E, F). The Po contained a horseshoe-shaped apical pore (foramen), and an elongated callus. The apical pore was surrounded by a row of marginal pores of equal sizes (Figs 3D, 7F). The first apical plate (1') was pentagonal and contacted the Po and the 2', 3', 1' and 6" plates (Figs 2A-C, 3A, B, 7A, E). Plate 2' was heptagonal in shape, and larger than plate 1' (Figs 
2B-D, 3B, 7E). Plate $3^{\prime}$ was hexagonal in shape and contacted the Po, 1', 2', 1a, 5" and 6" plates (Figs 2F, 3A, 7D, E). Plate 1a was pentagonal in shape and smaller than plates $2^{\prime}$ and $3^{\prime}$ (Figs 2E, 3B, C, 7C-E). Six precingular plates were arranged asymmetrically (Figs 2A-C, 3A, B, 7C, E). Plates 1" and 6" were hexagonal in shape (Figs 2A-C, 3A, B, 7C, E). Plates 2" and 4" were four-sided in shape (Figs 2C, E, 3B, 7B, C). Plates 3" and 5" were pentagonal in shape (Figs 2D-F, 3A, B, 7C, E). Plate 6" was narrow and smaller than plate 1" (Figs 2A, 3A, 7A). The cingulum was deeply excavated, formed by six plates and descending by about one cingulum width (Fig. 4A-D). The $\mathrm{C} 1$ plate of the cingular series was the smallest and encroached on the left-hand side of the anterior sulcal area (Fig. 4A). The C2 plate was in contact with the C1, C3, 1", 2", 1"' and 2"' plates (Fig. 4A, B). Plate C3 was the largest of the cingular plates (Fig. 4B, C). The suture of plate C2 with plate C3 was located after the sutures of plates 1" and 2" on the epitheca and plates 1"' and 2"' on the hypotheca (Fig. 4B). The suture of plate C3 with plate C4 was located before the sutures of plates $3 "$ and $4 "$ on the epitheca and plates $3^{\prime \prime \prime}$ and 4 "' on the hypotheca (Fig. 4C). Plate C6 was smaller than plate C5 (Fig. 4D). In the hypotheca, there were five postcingular plates $\left(5^{\prime \prime \prime}\right)$, two antapical plates $\left(2^{\prime \prime \prime}\right)$, and one posterior intercalary plate (1p) (Fig. 5A-D). The postcingular plates were symmetrically arranged (Fig. 5A). Plate 1"' with a well-developed list on its right-hand side was smaller than plate $2^{\prime \prime \prime}$, and contacted plate $1^{\prime \prime \prime \prime}$ (Fig. 5A, B). Plates $2^{\prime \prime \prime}$ and $4 " \prime$ were pentagonal in shape and contacted one of the antapical plates, and plate 1p (Fig. 5A-D). Plate 3"' was symmetrical and trapezoidal in shape (Fig. 5A). The posterior margin was very narrow and contacted plate 1p (Fig. 5B, D). Plate 5"' had a well-developed list on its left-hand side and was smaller than plate 4"' (Figs 2E, F, 5A). The anterior margin of plate 5"' was wide and contacted the C5 and C6 plates (Fig. 4D). The posterior margin of plate $5^{\prime \prime \prime}$ was narrow and contacted plate $2^{\prime \prime \prime \prime}$ (Fig. 5A). The antapical plates, $1^{\prime \prime \prime \prime}$ and $2^{\prime \prime \prime \prime}$, were pentagonal in shape, dissimilar in size, smaller than the five postcingular plates, and contacted the posterior sulcal area (Fig. 5A-C). Plate 1p was pentagonal in shape, and surrounded by three postcingular plates and two antapical plates: $2^{\prime \prime \prime}, 3^{\prime \prime \prime}$ and $4 " \prime, 1^{\prime \prime \prime \prime}$ and $2^{\prime \prime \prime \prime}$ (Fig. 5A-D). The sulcus was narrow, with welldeveloped lists on both sides (Figs 2A, 7A). The sulcus consisted of eight plates (Fig. 6A-D). The 
anterior sulcal plate (Sa) was long and large, located between plates 1" and 6", with a convex posterior margin (Fig. 6A). A ventral pore was on the plate Sa (Fig. 2B, 6A). Sometimes the ventral pore could hide below the bended rim of plate 6" and seem absent (Figs 6B, 7A). The right anterior sulcal plate (Sda) was larger than the Ssa, and connected to the 6", C6 and Sa plate (Fig. 6B, D). The left anterior sulcal plate (Ssa) was short and pentagonal in shape and did not connect to the $\mathrm{C} 1$ plate (Fig. 6D). The anterior median sulcal plate (Sma) and posterior median sulcal plate (Smp) were very small, located between the Ssa and the Sda (Fig. 6D). The right posterior sulcal plate (Sdp) and left posterior sulcal plate (Ssp) were narrow and more than twice as long as they were wide (Fig. 6D). The posterior sulcal plate (Sp) was narrow, symmetrically hexagonal, extended into the hypotheca without reaching the antapex (Fig. 6C). The external theca surface of the most cells was strongly areolated (Fig. 6E) and the internal surface of the theca was smooth (Fig. 6F). The areolae were irregular ellipsoid; at the bottom of the some areolae were $2-14$ small pores $0.1-0.3 \mu \mathrm{m}$ in diameter $(n=50)$ (Fig. $6 \mathrm{E}, \mathrm{F})$.

\section{Molecular Phylogeny}

\section{Concatenated SSU-ITS1-5.8S-ITS2-LSU}

The tree inferred from the concatenation of the SSU-ITS1-5.8S-ITS2-LSU sequences showed that $C$. punctatum is nested within the Alexandrium clade (Fig. 9). Maximum likelihood and Bayesian inference analyses generated four similar trees that differed with respect to only a few topological features (Fig. 9; Appendix S1). In this phylogeny, C. punctatum and Alexandrium species formed a clade with 100\% ML bootstrap support and 1.00 Bayesian PP (Fig. 9). The closest relative of C. punctatum was Alexandrium affine (H.Inoue \& Y.Fukuyo) Balech, which formed a well-supported clade with 99\% ML bootstrap support and 1.00 Bayesian PP. The clade of $C$. punctatum and A. affine was closely related to the clade of members of the Alexandrium tamarense species complex (100\% ML bootstrap support and 1.00 Bayesian PP). The well-supported clade consisting of $C$. punctatum and Alexandrium species was sister to the clade with Triadinium Pouchet and Gambierdiscus Adachi \& Fukuyo (100\% ML bootstrap support and 1.00 
Bayesian PP).

The individual gene trees (SSU, LSU and ITS) resulted in a same pattern as observed in the multiple genes trees (Appendix S1). In a phylogenetic tree based on the SSU rDNA sequence, two Korean and two French strains of $C$. punctatum formed a monophyletic group with the highest support (100\% ML bootstrap support and 1.00 Bayesian PP) (Appendix S1).

\section{Concatenated SSU- ITS1-5.8S-ITS2-LSU-Cox1-Cob-Hsp90}

The phylogenetic position of $C$. punctatum was also inferred from SSU-ITS1-5.8S-ITS2-LSU-Cox1-CobHsp90 gene sequences obtained in the present study (Fig. 10); the sequence accession numbers are shown in Appendix S2. Maximum likelihood and Bayesian inference analyses generated four similar trees that differed with respect to only a few topological features (Fig. 10). The dinoflagellates were found to be a monophyletic group with 100\% ML bootstrap support and 1.00 Bayesian PP. Of the dinoflagellates included in the analyses, the earliest diverging was found to be Noctiluca scintillans (Macartney) Kofoid \& Swezy. The order of Gonyaulacales was resolved as monophyletic with significant bootstrap support (100\% ML bootstrap support and 1.00 Bayesian PP). C. punctatum was also nested within the Alexandrium clade and the two strains formed a subclade with 100\% ML bootstrap support and 1.00 Bayesian PP. C. punctatum was sister to Alexandrium affine, which formed a well-supported clade with 100\% ML bootstrap support and 1.00 Bayesian PP. The clade of C. punctatum and A. affine formed a sister clade to members of the Alexandrium tamarense species complex. This phylogenetic analyses also indicated that Alexandrium was not monophyletic (100\% ML bootstrap support and 1.00 Bayesian posterior probability [PP]).

\section{Discussion}

\section{Morphological Comparison of Centrodinium punctatum with Other Fusiform Dinoflagellates}


Historically, armored fusiform dinoflagellates have been classified primarily on the basis of morphological features, such as cell size, plate formula and cingulum offset (e.g., Balech 1962; Carbonell-Moore 1996; Hernández-Becerril et al. 2010; Kofoid 1907; Sournia 1986; Taylor 1976). The external shape of $C$. punctatum is quite similar to those of the fusiform dinoflagellates Gonyaulax birostris Stein and Spiraulax jolliffei (Murray \& Whitting) Kofoid re-described by Carbonell-Moore (1996). However, the cell sizes of G. birostris and S. jolliffei (>100 $\mu \mathrm{m}$ in length) are much larger than $C$. punctatum. The cingulum of $C$. punctatum is displaced by only one cingular width, whereas the cingulum displacement of Gonyaulax and Spiraulax species is more than one cingular width. In addition, $G$. birostris and $S$. jolliffei have two anterior intercalary plates and six postcingular plates (Carbonell-Moore 1996), whereas $C$. punctatum has only one anterior intercalary plate and five postcingular plates.

Although $C$. punctatum belongs to the genus Centrodinium, the morphological features of $C$. punctatum differ significantly from other Centrodinium species (e.g., Balech 1962; Böhm 1933; Hernández-Becerril et al. 2010; Kofoid 1907; Léger 1973; Pavillard 1930; Rampi and Bernhard 1980; Schiller 1937; Sournia 1986; Steidinger and Tangen 1997; Taylor 1976); most Centrodinium species are usually large (>200 $\mu \mathrm{m}$ in length) and strongly compressed laterally, with a delicate theca without areolation, whereas $C$. punctatum has a strongly areolated theca, relatively small size, and is not compressed laterally.

The thecal plate formula of C. punctatum has been interpreted differently (e.g., Schiller 1937; Balech 1962; Hernández-Becerril et al. 2010). The plate formula of C. punctatum provided by Schiller (1937) was 2' (or 4'), 0a, 5", 5'", 1p, 4'"', however Wood (1954) suggested the possible presence of an anterior intercalary plate (1a). Later, Balech (1962) suggested the presence of three anterior intercalary plates and five cingular plates, and considered the correct formula to be 2', 3a, 7", 5C, 5"', 1p, 1'"'. Later, Balech (1971) demonstrated the presence of a Po plate in C. punctatum and also variable development of sulcal lists and a strongly ornamented theca. Sournia (1986) suggested an approximate formula for the genus Centrodinium: Po (?), 2-3', 1-3a, 6-7", 5-6C, ?S, 5'", 1-2p, 1'"'. Okolodkov and Dodge (1997) studied $C$. 
punctatum using SEM and found a tabulation that is different from what was found in this study (Po, 3', $\left.0 \mathrm{a}, 6^{\prime \prime}, 6^{\prime \prime \prime}, 1 \mathrm{p}, 1^{\prime \prime \prime \prime}\right)$ : they did not recognize any anterior intercalary plates, but recorded six postcingular plates. Since the authors express doubt about their interpretation of the tabulation, their specimens could represent the same species as the one observed in this study.

Based on SEM observations, Hernández-Becerril et al. (2010) proposed the plate formula of $C$. pulchrum (Po, 3', 3a, 6", 6C, 5S, 5'"', 2p, 1'"'), and extended it to other species of the genus Centrodinium. Accordingly, Centrodinium species described in previous studies have one or three anterior intercalary plates and only four or five plates in the sulcus (e.g., Hernández-Becerril et al. 2010; Sournia 1986). However, in contrast to C. pulchrum, C. punctatum has only one anterior intercalary plate that is not particularly laterally flattened. In addition, the cingular plates of $C$. pulchrum are almost equal in size, whereas the C1 plate of C. punctatum is very small (Balech 1967; Hernández-Becerril et al. 2010). On the basis of morphological differences between $C$. punctatum and other Centrodinium species, C. punctatum may be considered as a distinct species from other Centrodinium species. However, since the tabulation of many Centrodinium species, including the type species C. elongatum, is lacking or incomplete, further observations of Centrodinium species, specifically the type, are needed to confirm the assignment of $C$. punctatum to Centrodinium.

\section{Unexpected Phylogenetic Position of Centrodinium punctatum}

Interestingly, despite the fact that the morphological features of $C$. punctatum are quite similar to those of other fusiform dinoflagellates, the eight-gene phylogeneties, and the individual gene analysis based on SSU, ITS region (ITS1, ITS2 and 5.8S rDNA) and LSU rDNA sequences revealed that $C$. punctatum shows a close relationship with the Alexandrium clade (Figs 9-10, Appendix S1), and that C. punctatum displays the closest genetic resemblance to A. affine. The phylogenetic placement of $C$. punctatum begs the question whether this species produces paralytic shellfish toxins (PST). For that reason, the $A 1$ and $A 4$ domains of the sxtA gene were amplified using the methods of Stüken et al. (2011), the result however 
revealed that Korean strains lack the saxitoxin genes (unpublished data). According to Orr et al. (2011) and Murray et al. (2014), A. affine is a non-STX producing species at the base of the clade containing most of the PST producing Alexandrium species. The close genetic relationship between A. affine and $C$. punctatum is thus supported by the absence of toxicity.

The classification of dinoflagellates is usually based on the combination of morphological and phylogenetic data of vegetative cells, and accordingly the morphological descriptions of dinoflagellates have usually reflected their phylogenetic relationships. Despite the significant morphological differences between $C$. punctatum and Alexandrium species (see next section), it is surprising that the phylogenetic position of $C$. punctatum is nested within the genus Alexandrium. The genus Alexandrium has been considered as a monophyletic group (Saunders et al. 1997). Under the present circumstances, the phylogenetic placement of $C$. punctatum makes the genusAlexandriumi non-monophyletic, and an immediate solution is not readily available. A similar situation has arisen for other dinoflagellate genera that encompass many species: Gymnodinium s.str. consists not only of Gymnodinium-like species but also of polykrikoids and warnowiids (e.g., Hoppenrath et al. 2009), Gonyaulax consists of different cyst-based genera (Mertens et al. 2017) and Protoperidinium as well (Gu et al. 2015). In addition, Logares et al. (2007) documented that Scrippsiella hangoei and Peridinium aciculiferum, which have significant morphological and physiological differentiation, can have identical rDNA sequences. Consequently, similar DNA sequences do not always reflect the same morphological characteristics. However, as the molecular data of other Centrodinium species have not been determined, further studies are needed to clarify the molecular phylogeny of other Centrodinium species.

\section{Possible Morphological Relationship Between Centrodinium punctatum and Alexandrium species}

C. punctatum is clearly distinguished from Alexandrium species by its tabulation; the plate tabulation of $C$. punctatum is Po, 3', 1a, 6", 6C, 8S, 5"', 1p, 2"'"', whereas Alexandrium species exhibit Po, 4', 6", 6C, 9-10S, 5"', $2^{\prime \prime \prime \prime}$ as a plate tabulation (Balech 1995). However, in another Gonyaulacoid, Protoceratium reticulatum 
(Claparède \& Lachmann) Bütschli, the 1a plate is sometimes considered to be an apical plate (e.g., Hansen et al. 1997; Wołoszyńska 1929), suggesting that the 3' plate of Alexandrium may be a homologue to the 1a plate of $C$. punctatum. In addition, the sulcal plate arrangement of $C$. punctatum is similar to the Alexandrium species (e.g., Balech 1995); the Sa, Sda, Sma and Ssa plates comprise the anterior part of the sulcus and the Sdp, Smp, Ssp and Sp are located on the opposite posterior part.

In the antapical region, the plate tabulation can be considered a fundamental difference between $C$. punctatum and Alexandrium species. In both genera, there are two antapical plates and one posterior intercalary plate (1p), but the two genera differ in the arrangement and position of these three plates. As the precise homology of these plates should be revealed by study of the overlap in both genera, this is beyond the scope of this study.

Most armored dinoflagellates have a Po that can be distinct feature for generic identification (Hoppenrath 2017). The Po in the apical area of the fusiform species, such as Centrodinium and Spiraulax, has not been described so far, however based on SEM observations of C. punctatum, a small Po composed of a horseshoe-shaped apical pore and many marginal pores is observed, indicating that the Po is similar to the comma-shaped apical pores of Alexandrium species described by Balech (1995), MacKenzie et al. (2004) and John et al. (2014). These results are confirmed by the molecular phylogenies of Gonyaulacales; C. punctatum, Alexandrium and Pyrodinium species form a well-supported clade (Fig. S3 in Supporting Information Appendix S1), whereas the genera Gambierdiscus, Gonyaulax, Lingulodinium, Protoceratium, Tripos and Triadinium that have a slit-like or hook-shaped apical pore are nested within other clades (Dodge and Hermes 1981; Taylor and Fukuyo 1989; Shin et al. 2016). In addition, the Po of $C$. punctatum is quite similar to the Po of the sand-dwelling gonyaulacoid taxa Thecadinium arenarium Yoshimatsu, Toriumi \& Dodge and T. yashimaense Yoshimatsu, Toriumi \& Dodge; these species have a horseshoe-shaped apical pore and many marginal pores (Hoppenrath et al. 2004; Yoshimatsu et al. 2004). However, T. arenarium and T. yashimaense only have one antapical plate, and the cingulum of Thecadinium species forms a steep left-handed spiral. 
To understand the unexpected phylogenetic position of $C$. punctatum within Alexandrium species, the morphological comparisons in the present study are entirely based on morphological features of vegetative cells. Some taxonomic studies revealed that the morphological features of resting stages of dinoflagellates can contribute to the taxonomy and classification of dinoflagellates (e.g., Li et al. 2015; Sarai et al. 2013; Shin et al. 2014). For example, in the genus Alexandrium, the resting cyst morphology provides further support for separating species of the A. tamarense species complex and others; they each produce a different type of resting cyst, ellipsoidal or spherical (e.g., Shin et al. 2014). In addition, as the internal morphology, such as dinokaryon, amphiesma and flagellar apparatus, is important for dinoflagellate classification (e.g., Daugbjerg et al. 2000; Hansen and Moestrup 1998), future studies are needed to examine its ultrastructure and establish the cyst-theca relationship for $C$. punctatum and related species.

\section{Taxonomic Summary}

Many species of armored fusiform dinoflagellate species remain poorly known. The present study provided morphological details and molecular data that may allow for characterization of the studied species and to determine its taxonomic position. The present species was closely related to Alexandrium species, based on molecular phylogenetic placement. Taylor (1976), Gómez et al. (2015) and other authors have placed Centrodinium in the family Oxytoxaceae (Peridiniales) and Alexandrium in the family Goniodomataceae (Gonyaulacales). As described above, Centrodinium punctatum has the following morphological features; the $1^{\prime}$ plate is asymmetrical, one posterior intercalary plate, and a horseshoe-shaped apical pore, and the flagellar pore contacts the sulcal anterior plate and the sulcal additional dextral plate touches the cingulum. These morphologies are concordant with the circumscription of the Gonyaulacales given by Fensome et al. (1993). Thus, the genus Centrodinium should be placed within the Gonyaulacales rather than the Peridiniales. Kawai and Nakayama (2015) revised the taxonomic placement of Centrodinium and Alexandrium and transferred both genera to the 
family Heteraulacaceae (Peridiniales or Gonyaulacales). However, Heteraulacaceae is considered a synonym of Thoracosphaeraceae and its alternative Goniodomataceae has been rejected; Pyrophacaceae and Ostreopsiaceae are available to replace Goniodomatacae (Elbrächter and Gottschling 2015; Prud'homme van Reine 2017). Here it is suggested to use Pyrophacaceae to affiliate Alexandrium and Centrodinium because it has priority over Ostreopsiaceae (it appears earlier in Lindemann 1928 and thus has priority).

\section{Centrodinium punctatum (Cleve) F.J.R. Taylor emended Z. Li, K.N. Mertens, E. Nézan, N.}

\section{Chomérat, M. Iwataki and H.H. Shin}

Emended diagnosis: Armored marine dinoflagellates. Cells solitary, yellow-green in color. Cells broadly fusiform, not laterally compressed, $40.7-80.6 \mu \mathrm{m}$ in length, $19.5-40.9 \mu \mathrm{m}$ in width, $21.4-39.9 \mu \mathrm{m}$ in depth (dorso-ventral axis), average width-to-depth ratio 1.1. Cingulum subequatorial, descending, displaced one cingular width. Sulcal lists more developed, slightly deeper than the surrounding plates, located centrally at the apex of the cell. Theca strongly areolated. Plate formula Po, 3', 1a, 6", 6C, 8S, 5"', $1 \mathrm{p}, 2^{\prime \prime \prime \prime}$. Apical pore horseshoe-shaped. Nucleus elongated, sausage-shaped and located centrally on the left side of the cell. Chloroplasts present.

Holotype: Cleve 1900, Plate VIII. Fig. 4.

Basionym: Steiniella punctata Cleve 1900 (Kungl. Svenska vetenskapsakademiens handlingar. 34: 18, Plate VIII. Fig. 4.)

Synonyms: Steiniella punctata Cleve 1900; Murrayella punctata (Cleve) Kofoid 1907; Pavillardinium punctatum (Cleve) de Toni 1936; Murrayella splendida Rampi 1941; Pavillardinium splendidum (Rampi) Rampi 1950 [fide Hernández-Becerril et al. 2010], “C. mimeticum (Balech) Taylor 1976” sensu Dodge (1985, p. 114).

Type Locality: Atlantic Ocean: $48^{\circ} \mathrm{N}, 24^{\circ} \mathrm{W}$ 
Distribution: East China Sea of the Pacific Ocean, offshore Réunion island of the Indian Ocean, and French Atlantic coast.

Authentic Culture Strain: Deposited at the Library of Marine Samples, Korea Institute of Ocean Science and Technology, Geoje 53201, Republic of Korea, under the strain number LIMS-PS-2525.

\section{Methods}

Sampling, and isolation and light microscopy of cells collected from East China Sea: Plankton samples were collected during the RV Onnuri cruise in the East China Sea from 16 to 24 August 2016 using a $20 \mu \mathrm{m}$-mesh plankton net. Single cells were isolated immediately on the research vessel using a capillary pipette under a light microscope (Eclipse 50i; Nikon, Japan). The isolated cells were inoculated into individual wells of 48-well culture plates (Eppendorf, Germany) filled with sterile F/2 culture medium (Marine Water Enrichment Solution, Sigma-Aldrich, MO, USA) and cultured at room temperature $\left(22^{\circ} \mathrm{C}\right)$ under continuous white light during the sampling periods.

In the laboratory, the cultured cells were transferred to the individual wells of six-well tissue plates by micropipetting. The cells were incubated at $20{ }^{\circ} \mathrm{C}$ and ca. $100 \mu \mathrm{mol}$ photons $\mathrm{m}^{-2} \mathrm{~s}^{-1}$ cool-white illumination under a 14L:10D photo-cycle. Live cells were isolated from the six-well tissue plates, examined and photographed at $\times 1000$ magnification using an ultra-high resolution digital camera (DSRi2; Nikon, Japan) on an upright microscope (ECLIPSE Ni; Nikon, Japan). After sufficient growth, the cells in the six-well tissue plates were transferred to a culture flask (70025; SPL Life Science, Korea) containing $25 \mathrm{~mL}$ sterile F/2 medium. Two culture strains were established successfully, and have been deposited in the Library of Marine Samples, Korea Institute of Ocean Science and Technology, Republic of Korea, as strain numbers LIMS-PS-2525 and LIMS-PS-2526.

For fluorescence microscopy, approximately $1 \mathrm{~mL}$ of live, healthy cell culture (LIMS-PS-2525) was transferred to a 1.5-mL microcentrifuge tube, and SYTOX ${ }^{\circledR}$ Green Nucleic Acid Stain (Molecular Probes, 
Eugene, OR, USA) was added at a final concentration of $1.0 \mu \mathrm{M}$. The cells were incubated in the dark at room temperature for $30 \mathrm{~min}$. The cells were observed through a Zeiss Filterset (emission: BP 450-490; beam splitter: FT 510) and photographed using an AxioCam MRc digital camera on an upright microscope (Axio Imager 2; Zeiss, Germany). The Kofoidian system was used to designate the thecal plates (Fensome et al. 1993).

Scanning electron microscopy (SEM) of specimens from East China Sea: For the cultures from East China Sea, $2 \mathrm{~mL}$ of mid-exponential batch culture (LIMS-PS-2525) was fixed with 2.0\% osmium tetroxide (Sigma-Aldrich) for $15 \mathrm{~min}$ at room temperature, then rinsed with sterile-filtered seawater and deionized water. After rinsing, the samples were dehydrated in a graded ethanol series (1099.9\% in eight steps) for 15 min at each step. The samples were then critical point dried using a critical point drying (SPI-Dry Regular Critical Point Dryer, SPI Supplies, West Chester, PA, USA) from liquid $\mathrm{CO}_{2}$. Finally, the samples were coated with platinum and examined under a JEOL JSM 7600F field emission scanning electron microscope (JEOL Ltd, Tokyo, Japan).

Sampling and isolation for SEM from offshore Réunion Island, Indian Ocean: Plankton samples were collected with a plankton net $(20 \mu \mathrm{m})$ on 9 November 2016 from Grande Anse, offshore Réunion Island, Indian Ocean $\left(55.54{ }^{\circ} \mathrm{E},-21.37^{\circ} \mathrm{S}\right)$ and fixed with acidic Lugol's Iodine solution $(0.1 \%$ final concentration) (Andersen and Throndsen 2003).

For SEM, single specimens were isolated from the plankton samples from Réunion Island using a micropipette on a IX70 (Olympus) inverted microscope. The cells were deposited on polycarbonate membrane filters (GTTP Isopore, $0.22 \mu \mathrm{m}$ pore size; Millipore, Billerica, MA, USA), which were rinsed with distilled water and stuck to a stub using double-sided adhesive tape. The stubs were air-dried, sputter-coated with gold, and examined using a Sigma 300 Gemini (Carl Zeiss Inc., Oberkochen, Germany) field-emission SEM equipped with both a conventional Everhart-Thornley and in-lens secondary electron detectors at $1.5 \mathrm{kV}$..

DNA extraction and sequencing of specimens from East China Sea: Genomic DNA was 
extracted from $1 \mathrm{~mL}$ of exponentially growing cultures of strains LIMS-PS-2525 and LIMS-PS-2526 using the DNeasy ${ }^{\circledR}$ Plant Mini Kit (QIAGEN Inc., Valencia, CA, USA) following the manufacturer's instructions. The SSU rDNA sequence was amplified using the primer pairs SR1 and SR9, SR4 and SR12b, and DIN464F and EK-1498R (Gómez et al. 2009, 2010; Yamaguchi and Horiguchi 2005). Part of the LSU rDNA sequence was amplified using the primer pairs D1R and R2 (Takano and Horiguchi 2006), and 25F1 and 25R1 (Yamaguchi and Horiguchi 2005). The PCR was conducted using a thermoblock (T100 ${ }^{\mathrm{TM}}$ Thermal Cycler; Bio-Rad, USA) at $95{ }^{\circ} \mathrm{C}$ for $2 \mathrm{~min}$, followed by 35 cycles of denaturation at $94{ }^{\circ} \mathrm{C}$ for $30 \mathrm{~s}$, annealing at $55^{\circ} \mathrm{C}$ for $30 \mathrm{~s}$, and extension at $72{ }^{\circ} \mathrm{C}$ for $2 \mathrm{~min}$. The reaction was completed with a final elongation at $72{ }^{\circ} \mathrm{C}$ for $5 \mathrm{~min}$. The ITS1-5.8S-ITS2 sequence was amplified using the primer pairs ITS1 and ITS4 (White et al. 1990), ITSFor and ITSRev (Murray et al. 2012). Amplification conditions were $95{ }^{\circ} \mathrm{C}$ for $5 \mathrm{~min}$, followed by 35 cycles at $95{ }^{\circ} \mathrm{C}$ for $1 \mathrm{~min}$; at $52{ }^{\circ} \mathrm{C}$ for $1 \mathrm{~min}$; and at $72{ }^{\circ} \mathrm{C}$ for 2 min with a final extension step at $72{ }^{\circ} \mathrm{C}$ for 7 min. The sequences of Cox 1 and $\mathrm{Cob}$ was amplified using the primer pairs Dinocox1F and Dinocox1R, Dinocob1F and Dinocob1R, respectively (Lin et al. 2009). PCR for both Cox 1 and Cob was performed using the following program: $95{ }^{\circ} \mathrm{C}$ for 1 min, followed by 35 cycles of $20 \mathrm{~s}$ at $94{ }^{\circ} \mathrm{C}, 30 \mathrm{~s}$ at $56{ }^{\circ} \mathrm{C}$, and $30 \mathrm{~s}$ at $72{ }^{\circ} \mathrm{C}$, and finally an elongation step of $7 \mathrm{~min}$ at $72{ }^{\circ} \mathrm{C}$. Hsp90 sequences were amplified using the primer pairs F4 and R2 (Hoppenrath and Leander 2010), and High Fidelity PrimeSTAR® GXL DNA Polymerase (TaKaRa Bio Inc., Japan). PCR amplifications consisted of $95{ }^{\circ} \mathrm{C}$ for $5 \mathrm{~min} ; 35$ cycles of 35 cycles of $10 \mathrm{~s}$ at $98{ }^{\circ} \mathrm{C}, 30 \mathrm{~s}$ at $55{ }^{\circ} \mathrm{C}$, and $1 \mathrm{~min}$ at $68{ }^{\circ} \mathrm{C}$; and a final extension period at $68{ }^{\circ} \mathrm{C}$ for $5 \mathrm{~min}$. For single-cell PCR analysis, a single cell was isolated and transferred to a $200 \mu$ thin-wall PCR tube (Axygen, Union City, CA, USA). PCR amplification was carried out in a 50- $\mu 1$ reaction volume with KOD-plus-DNA Polymerase (Toyobo, Osaka, Japan). Primers for amplification of SSU, ITS and partial LSU rDNA were SR1 and R2 for the first round PCR. Takara Ex Taq DNA Polymerase (TaKaRa Bio Inc., Japan) was used for the other rounds of PCR. The SSU, ITS and partial LSU rDNA sequences were amplified using the primer pairs SR1 and SR9, SR4 and SR12b, DIN464F and EK-1498R, ITSFor and ITSRev, and D1R and R2 were 
also employed. The PCR-amplified products were confirmed by $1 \%$ agarose gel electrophoresis. The PCR products were purified using the QIAquick PCR Purification Kit (QIAGEN). The cycle sequencing reaction was performed using the ABI PRISM ${ }^{\circledR}$ BigDye $^{\mathrm{TM}}$ Terminator Cycle Sequencing Ready Reaction Kit (Applied Biosystems, USA). The sequences of the strains LIMS-PS-2525 and LIMS-PS-2526 were re-sequenced in the University of Tokyo, Japan.

Single-cell PCR of specimens from French Atlantic coast: For DNA amplification, single cells of Centrodinium punctatum were isolated from plankton samples collected with a plankton net (20 $\mu \mathrm{m})$ on 9 December 2014 and 6 January 2015 in Concarneau Bay, French Atlantic and fixed with acidic Lugol's Iodine solution $(0.1 \%$ final concentration) under an Olympus IX70 inverted light microscope (Olympus, Tokyo, Japan), and deposited on a glass slide. They were observed at $600 \times$ magnification, photographed with an Olympus DP72 digital camera (Olympus, Tokyo, Japan), and rinsed with double distilled water (Milli-Q water; Millipore) before transfer to a $0.2 \mathrm{~mL}$ PCR tube containing $3 \mu \mathrm{L}$ of Milli-Q water. PCR tubes were stored at $-20{ }^{\circ} \mathrm{C}$ until direct PCR amplifications. For PCR, tubes were thawed and processed as described in Nézan et al. (2012). The nuclear marker SSU rDNA was amplified using the primers 18S-FW and 18S-RV (Chomérat et al. 2010).

Multiple sequence alignments and phylogenetic analysis: Sequences were viewed and assembled in DNABaser version 4.36 (http://www.dnabaser.com). Contigs were imported into MEGA version 7.0 (Kumar et al. 2016) and aligned using ClustalW with default settings. Sequence alignments were manually edited using BioEdit version 7.2.5, excluding poorly aligned positions (Hall 1999). The GTR $+\mathrm{I}+\mathrm{G}$ substitution model was selected using the Akaike information criterion as implemented in in jModelTest version 2.1.4 (Darriba et al. 2012). The final alignment of the SSU rDNA dataset consisted of 52 taxa and contained 1617 characters (including gaps inserted for alignment). Two sequences of the unarmored dinoflagellate Karlodinium veneficum (D.Ballantine) J.Larsen (GenBank accession numbers JF791046 and JF791048) were used as the outgroup. For the analysis of LSU rDNA sequences, the dataset contained 53 taxa and consisted of 1336 characters (including gaps inserted for alignment). 
Sequences of the unarmored dinoflagellate $K$. antarcticum de Salas (GenBank accession number EF469234) and $K$. decipiens de Salas \& Laza-Martinez (EF469236) were used as the outgroup. For the analysis of ITS1-5.8S-ITS2 sequences, the dataset contained 44 taxa and consisted of 663 characters (including gaps inserted for alignment). Sequences of the unarmored dinoflagellate $K$. australe de Salas, Bolch \& Hallegraeff (KJ670420) and K. veneficum (AF352367) were used as the outgroup. The separate alignments were then checked and concatenated using SequenceMatrix version 1.8 (Vaidya et al. 2011). The alignment of the concatenated dataset consisted of 29 taxa and 3,724 bp for SSU/ ITS /LSU (including gaps inserted for alignment). The sequence of the unarmored dinoflagellate Gymnodinium aureolum (Hulburt) G. Hansen (DQ779991) was used as the outgroup. The final alignment of the concatenated dataset consisted of 34 taxa and 7,394 bp for SSU/ ITS /LSU/Cox1/Cob/Hsp90 (including gaps inserted for alignment). Sequences of perkinsozoans were used as outgroup.

Phylogenetic trees derived from each dataset were constructed using maximum likelihood (ML) and Bayesian inference analyses. The ML analyses were performed using PhyML version 3.1 (Guindon et al. 2010). The starting tree was generated using BIONJ with optimization of the topology, branch lengths, and selected rate parameters. Six different substitution rates were selected. Bootstrap analyses of both datasets were carried out for ML with 1000 replicates to assess statistical reliability. Bayesian inference analyses were conducted on five datasets using MrBayes version 3.2 (Ronquist et al. 2012). The evolutionary model used in Bayesian inference analyses were the GTR+I+G model with gammadistributed rate variation across sites. Five Markov chain Monte Carlo (MCMC) chains were run for 10 million generations, sampling every 100 generations.

\section{Acknowledgements}


This work was supported by grants from the Marine Biotechnology Program of the Korea Institute of Marine Science and Technology Promotion (KIMST) funded by the Ministry of Oceans and Fisheries (MOF) (No. 20170431), and Korea Institute of Ocean Science and Technology (KIOST) project (PE99721). We thank Alina Tunin-Ley (Hydrô Réunion) for sampling offshore waters on Réunion Island.

The Regional Council of Brittany, the General Council of Finistère and the urban community of Concarneau-Cornouaille-Agglomération are acknowledged for the funding of the Sigma 300 FE-SEM of the station of Marine Biology in Concarneau. Malte Elbrächter is acknowledged for taxonomic advice.

\section{References}

Andersen P, Throndsen J (2003) Estimating Cell Numbers. In Hallegraeff GM, Anderson DM,

Cembella AD (eds) Manual on Harmful Marine Microalgae. UNESCO, Paris, pp 99-129

Balech E (1962) Tintinnoinea y dinoflagellata del Pacífico según material de las expediciones Norpac y Downwind del Instituto Scripps de Oceanografía. Rev Mus Arg Cs Nat “B Rivadavia” C Zool 7:1-253

Balech E (1967) Dinoflagelados nuevos o interesantes del Golfo de México y Caribe. Rev Mus Arg Cs Nat “'B Rivadavia”’ Hidrobiol 2:77-144

Balech E (1971) Microplancton del Atlántico Ecuatorial Oeste (Equalant I). Armada Argentina, Servicio Hidrográfico Naval H 654: 1-103

Balech E, ed (1995) The genus Alexandrium Halim (Dinoflagellata). Sherkin Island Marine Station, Co. Cork, $151 \mathrm{p}$

Böhm A (1933) Zur Verbreitung einiger Dinoflagellaten im Südatlantik. Bot Arch 35:397-407

Carbonell-Moore MC (1996) On Spiraulax jolliffei (Murray et Whitting) Kofoid and Gonyaulax fusiformis Graham (Dinophyceae). Bot Mar 39:347-370 
Chomérat N, Sellos DY, Zentz F, Nézan E (2010) Morphology and molecular phylogeny of Prorocentrum consutum sp. nov. (Dinophyceae), a new benthic dinoflagellate from South Brittany (Northwestern France). J Phycol 46:183-194

Darriba D, Taboada GL, Doallo R, Posada D (2012) jModelTest 2: more models, new heuristics and parallel computing. Nat Methods 9:772-772

Daugbjerg N, Hansen G, Larsen J, Moestrup Ø (2000) Phylogeny of some of the major genera of dinoflagellates based on ultrastructure and partial LSU rDNA sequence data, including the erection of three new genera of unarmoured dinoflagellates. Phycologia 39:302-317

de Toni G (1936) Noterelle di nomenclatura algologica, VI. II genere Murayella Kofoid 1907 (Peridinee). Pubished by the author, Brescia, Italia, $2 \mathrm{p}$

Dodge JD, ed (1982). Marine Dinoflagellates of the British Isles. Her Majesty's Stationery Office, London, 303p.mez F (2012) A quantitative review of the lifestyle, habitat and trophic diversity of dinoflagellates (Dinoflagellata, Alveolata). Syst Biodivers 10: 267-275.

Gómez F, López-García P, Moreira D (2009) Molecular phylogeny of the ocelloid-Bearing dinoflagellates Erythropsidinium and Warnowia (Warnowiaceae, Dinophyceae). J Eukaryot Microbiol 56:440-445

Gómez F, Moreira D, López-García P (2010) Neoceratium gen. nov., a new genus for all marine species currently assigned to Ceratium (Dinophyceae). Protist 161:35-54

Gómez F, Qiu D, Lopes RM, Lin S (2015) Fukuyoa paulensis gen. et sp. nov., a new genus for the globular species of the dinoflagellate Gambierdiscus (Dinophyceae). PLoS ONE 10:e0119676

Gu H, Liu T, Mertens KN (2015) Cyst-theca relationship and phylogenetic positions of Protoperidinium (Peridiniales, Dinophyceae) species of the sections Conica and Tabulata. Phycologia 54:49-66

Guindon S, Dufayard JF, Lefort V, Anisimova M, Hordijk W, Gascuel O (2010) New algorithms and methods to estimate maximum-likelihood phylogenies: assessing the performance of PhyML 3.0. Syst Biol 59: 307-321. 
Hall TA (1999) BioEdit: a user-friendly biological sequence alignment editor and analysis program for Windows 95/98/NT. Nucleic Acids Symp Ser 41:95-98

Hansen G, Moestrup Ø (1998) Fine-structural characterization of Alexandrium catenella (Dinophyceae) with special emphasis on the fagellar apparatus. Eur J Phycol 33:281-291

Hansen G, Moestrup Ø, Robert KR (1997) Light and electron microscopical observations on Protoceratium reticulatum (Dinophyceae). Arch Protistenkd 147:381-391

Hernández-Becerril DU, Bravo-Sierra E, Ceballos-Corona JGA, Esqueda-Lara K, EscobarMorales S, Parra-Toriz D (2010) Morphology and taxonomy of the marine planktonic dinoflagellate Centrodinium pulchrum Böhm (Dinophyta) from the tropical Mexican Pacific, with comments on the taxonomy and distribution of the genus Centrodinium. Phycologia 49:461-470

Hoppenrath M (2017) Dinoflagellate taxonomy - a review and proposal of a revised classification. Mar Biodiv 47:381-403

Hoppenrath M, Leander BS (2010) Dinoflagellate phylogeny as inferred from heat shock protein 90 and ribosomal gene sequences. PLoS ONE 5(10):e13220.

Hoppenrath M, Bachvaroff TR, Handy SM, Delwiche CF, Leander BS (2009) Molecular phylogeny of ocelloid-bearing dinoflagellates (Warnowiaceae) as inferred from SSU and LSU rDNA sequences. BMC Evol Biol 9:116

Hoppenrath M, Saldarriaga JF, Schweikert M, Elbrächter M, Taylor FJR (2004) Description of Thecadinium mисоsum sp. nov. (Dinophyceae), a new sand-dwelling marine dinoflagellate, and an emended description of Thecadinium inclinatum Balech. J Phycol 40:946-961

Janouškovec J, Gavelis GS, Burki F, Dinh D, Bachvaroff TR, Gornik SG, Bright KJ, Imanian B, Strom SL, Delwiche CF, Waller RF, Fensome RA, Leander BS, Rohwer FL, Saldarriaga JF (2017) Major transitions in dinoflagellate evolution unveiled by phylotranscriptomics. Proc Natl Acad Sci USA 114: E171-E180

John U, Litaker RW, Montresor M, Murray S, Brosnahan ML, Anderson DM (2014) Formal 
revision of the Alexandrium tamarense species complex (Dinophyceae) taxonomy: The Introduction of five species with emphasis on molecular-based (rDNA) classification. Protist 165:779-804

Kawai H, Nakayama T (2015) Introduction (Heterokontobionta p.p.), Cryptophyta, Dinophyta, Haptophyta, Heterokontophyta (except Coscinodiscophyceae, Mediophyceae, Fragilariophyceae, Bacillariophyceae, Phaeophyceae, Eustigmatophyceae), Chlorarachniophyta, Euglenophyta. In Frey W (ed) Syllabus of Plant Families. Adolf Engler's Syllabus der Pflanzenfamilien. $13^{\text {th }}$ edn. Phototrophic Eukaryotic Algae. Glaucocystophyta, Cryptophyta, Dinophyta/Dinozoa, Haptophyta, Heterokontophyta/Ochrophyta, Chlorarachnniophyta/Cercozoa, Chlorophyta, Streptophyta p.p. Borntraeger Science Publishers, Stuttgart, pp 11-189

Kofoid CA (1907) Reports of the scientific results of the expedition to eastern tropical Pacific, in charge of Alexander Agassiz, by the U.S. Fish Comission Steamer 'Albatross', from October, 1904, to March, 1905, Liut. Commander L.M. Garret, U.S.N., commanding. IX. New species of dinoflagellates. Bull Mus Comp Zool 50:162-207

Kofoid CA, Swezy O (1921) The free-living unarmored Dinoflagellata. Mem Univ California 5:1-562

Kumar S, Stecher G, Tamura K (2016) MEGA7: Molecular Evolutionary Genetics Analysis Version 7.0 for Bigger Datasets. Mol Biol Evol 33:1870-1874

Léger G (1973) Diatomées et dinoflagellés de la mer Ligure. Systématique et distribution en juillet 1963. Bull Inst Océanogr Monaco 71:1-36

Logares R, Rengefors K, Kremp A, Shalchian-Tabrizi K, Boltovskoy A, Tengs T, Shurtleff A, Klaveness D (2007) Phenotypically different microalgal morphospecies with identical ribosomal DNA: a case of rapid adaptive evolution? Microb Ecol 53:549-561

Li Z, Oh SJ, Park J-W, Lim W-A, Shin HH (2017) Cyst-motile stage relationship, morphology and phylogeny of a new chain-forming, marine dinoflagellate Grammatodinium tongyeonginum gen. et sp. nov. from Korea. Phycologia 56:430-443

Li Z, Shin HH, Lim W-A, Lee T, Yoon YH, Han M-S (2015) Morphology and phylogeny of 
Pentapharsodinium jinhaense sp. nov. (Dinophyceae) producing a calcareous resting cyst. Phycologia 54:566-577

Lin S, Zhang H, Hou YB, Zhuang YY, Miranda L (2009) High-level diversity of dinoflagellates in the natural environment, revealed by assessment of mitochondrial cox 1 and cob genes for dinoflagellate DNA barcoding. Appl Environ Microbiol 75:1279-1290

Lindemann E (1928) Abteilung Peridineae (Dinoflagellatae). In Engler A (ed) Die natürlichen Pflanzenfamilien nebst ihren Gattungen und wichtgeren Arten inbesodere den Nutzpflanzen unter Mirwirkung zahlreicher hervorragender Fachgelehrten begründet von A. Engler und K. Prantl. Zweite stark vermehrte und verbesserte Aufl. Verlag von Wilhelm Engleman, Leipzig, pp 3-104

MacKenzie L, de Salas M, Adamson J, Beuzenberg V (2004) The dinoflagellate genus Alexandrium (Halim) in New Zealand coastal waters: comparative morphology, toxicity and molecular genetics. Harmful Algae 3:71-92

Mertens KN, Takano Y, Head MJ, Matsuoka K (2014) Living fossils in the Indo-Pacific warm pool: A refuge for thermophilic dinoflagellates during glaciations. Geology 42:531-534

Mertens KN, Takano Y, Gu H, Bagheri S, Pospelova V, Pieńkowski AJ, Leroy S, Matsuoka K (2017) Cyst-theca relationship and phylogenetic position of Impagidinium caspienense incubated from Caspian Sea surface sediments: evidence for heterospory within gonyaulacoid dinoflagellates. J Eukaryot Microbiol 64:829-842

Murray SA, Garby T, Hoppenrath M, Neilan BA (2012) Genetic cdiversity, morphological uniformity and polyketide production in dinoflagellates (Amphidinium, Dinoflagellata). PLoS ONE 7:e38253

Murray SA, Hoppenrath M, Orr RJS, Bolch C, John U, Diwan R, Yauwenas R, Harwood T, de Salas M, Neilan B, Hallegraeff G (2014) Alexandrium diversaporum sp. nov., a new non-saxitoxin producing species: phylogeny, morphology and sxtA genes. Harmful Algae 31:54-65

Nézan E, Tillmann U, Bilien G, Boulben S, Chèze K, Zentz F, Salas R, Chomerat N (2012) Taxonomic revision of the dinoflagellate Amphidoma caudata: transfer to the genus Azadinium 
(Dinophyceae) and proposal of two varieties, based on morphological and molecular phylogenetic analyses. J Phycol 48:925-939

Okolodkov Y, Dodge JD (1997) Morphology of some rare and unusual dinoflagellates from the northeastern Atlantic. Nova Hedwigia 64:353-365

Orr RJS, Stuken A, Rundberget T, Eikrem W, Jakobsen KS (2011) Improved phylogenetic resolution of toxic and non-toxic Alexandrium strains using a concatenated rDNA approach. Harmful Algae 10: $76-688$

Pavillard J (1930) Sur quelques formes intéressantes ou nouvelles du phytoplancton (Diatomées et Péridiniens) des Croisieres du Prince Albert 1er de Monaco. Bull Inst Océanogr Monaco 558:1-12

Prud'homme van Reine WF (2017) Report of the Nomenclature Committee for Algae: 15. Taxon 66: $191-192$

Rampi L, Bernhard M, eds (1980) Chiave per la determinazione delle peridinee pelagiche mediterranee. Comitato Nazionale Energia Nucleare, CNEN-RT/ BIO 8, Roma, Italia, 193 p

Ronquist F, Teslenko M, van der Mark P, Ayres DL, Darling A, Hohna S, Larget B, Liu L, Suchard MA, Huelsenbeck JP (2012) MrBayes 3.2: Efficient bayesian phylogenetic inference and model choice across a large model space. Syst Biol 61:539-542

Saldarriaga JF, Taylor FJ, Keeling PJ, Cavalier-Smith T (2001) Dinoflagellate nuclear SSU rRNA phylogeny suggests multiple plastid losses and replacements. J Mol Evol 53:204-213

Sarai C, Yamaguchi A, Kawami H, Matsuoka K (2013) Two new species formally attributed to Protoperidinium oblongum (Aurivillius) Park et Dodge (Peridiniales, Dinophyceae): evidence from cyst incubation experiments. Rev Palaeobot Palynol 192:103-118

Saunders GW, Hill DRA, Sexton JP, Andersen RA (1997) Small-subunit Ribosomal RNA Sequences From Selected Dinoflagellates: Testing Classical Evolutionary Hypotheses with Molecular Systematic Methods. In Bhattacharya D (ed) Origins of Algae and Their Plastids, Plant Systematics and Evolution, Suppl Vol 11, Springer-Verlag, New York, pp 237-259 
Schiller J, ed (1937) Dinoflagellatae (Peridineae). Teil II. Rabenhorst's Kryptogamen-Flora. Akademie Verlag, Leipzig, 590p

Schmitz F (1893) Die Gattung Lophothalia J. Ag. Ber Dtsch Bot Ges 11:212-232

Shin HH, Li Z, Kim ES, Youn JY, Jeon SG, Oh SJ, Lim W-A (2016) Morphology and phylogeny of Triadinium polyedricum (Pouchet) Dodge (Dinophyceae) from Korean coastal waters. Ocean Sci J 51:647-654

Shin HH, Baek SH, Li Z, Han M-S, Oh SJ, Youn SH, Kim YS, Kim D, Lim W-A (2014) Resting cysts, and effects of temperature and salinity on the growth of vegetative cells of the potentially harmful species Alexandrium insuetum Balech (Dinophyceae). Harmful Algae 39:175-184

Sournia A, ed (1986) Atlas du Phytoplancton Marin, Vol. I: Introduction, Cyanophycées, Dictyochophycées, Dinophycées et Raphidophycées. Editions du Centre National de la Recherche Scientifique, Paris, 219p

Steidinger KA, Tangen K (1997) Dinoflagellates. In Tomas CR (ed) Identifying Marine Phytoplankton. Academic Press, San Diego, pp 387-584

Stüken A, Orr RJS, Kellmann R, Murray SA, Neilan BA, Jakobsen KS (2011) Discovery of nuclearencoded genes for the neurotoxin saxitoxin in dinoflagellates. PLoS ONE 6(5):e20096

Takano Y, Horiguchi T (2006) Acquiring scanning electron microscopical, light microscopical and multiple gene sequence data from a single dinoflagellate cell. J Phycol 42:251-256

Taylor FJR (1976) Dinoflagellates from the international Indian Expedition. A report on material collected by the R. V. “Anton Bruun” 1963-64. Biblioth Bot 132:1-234

Taylor FJR, ed (1987) The Biology of Dinoflagellates. Blackwell Scientific Publications, London, 798p

Taylor FJR, Fukuyo Y (1989) Morphological Features of the Motile Cell of Pyrodinium bahamense. In Hallegraeff GM, MacLean JL (eds) Biology, Epidemiology and Management of Pyrodinium Red Tides. International Centre for Living Aquatic Resources Management, Manila, pp 207-217

Vaidya G, Lohman DJ, Meier R (2011) SequenceMatrix: concatenation software for the fast assembly 
of multi-gene datasets with character set and codon information. Cladistics 27:171-180

White TJ, Bruns T, Lee S, Taylor J (1990) Amplification and Direct Sequencing of Fungal Ribosomal RNA Genes for Phylogenetics. In Innis MA, Gelfand DH, Sninsky JJ, White TJ (eds) PCR Protocols: A Guide to Methods and Applications. Academic Press, New York, pp 315-322

Wołoszyńska J (1929) Dinoflagellatae Polskiego Baltyku i blot nad Piasnica. - Archivum Hydrobiologji i Rybactwa 3:153-278

Wood EJF (1954) Dinoflagellates of the Australian region. Aust J Mar Freshwater Res 5:171-351

Yamaguchi A, Horiguchi T (2005) Molecular phylogenetic study of the heterotrophic dinoflagellate genus Protoperidinium (Dinophyceae) inferred from small subunit rRNA gene sequences. Phycol Res 53:30-42

Yoshimatsu S, Toriumi S, Dodge JD (2004) Morphology and taxonomy of five marine sanddwelling Thecadinium species (Dinophyceae) from Japan, including four new species: Thecadinium arenarium sp. nov., Thecadinium ovatum sp. nov., Thecadinium striatum sp. nov. and Thecadinium yashimaense sp. nov. Phycol Res 52:211-223 


\section{Figures}

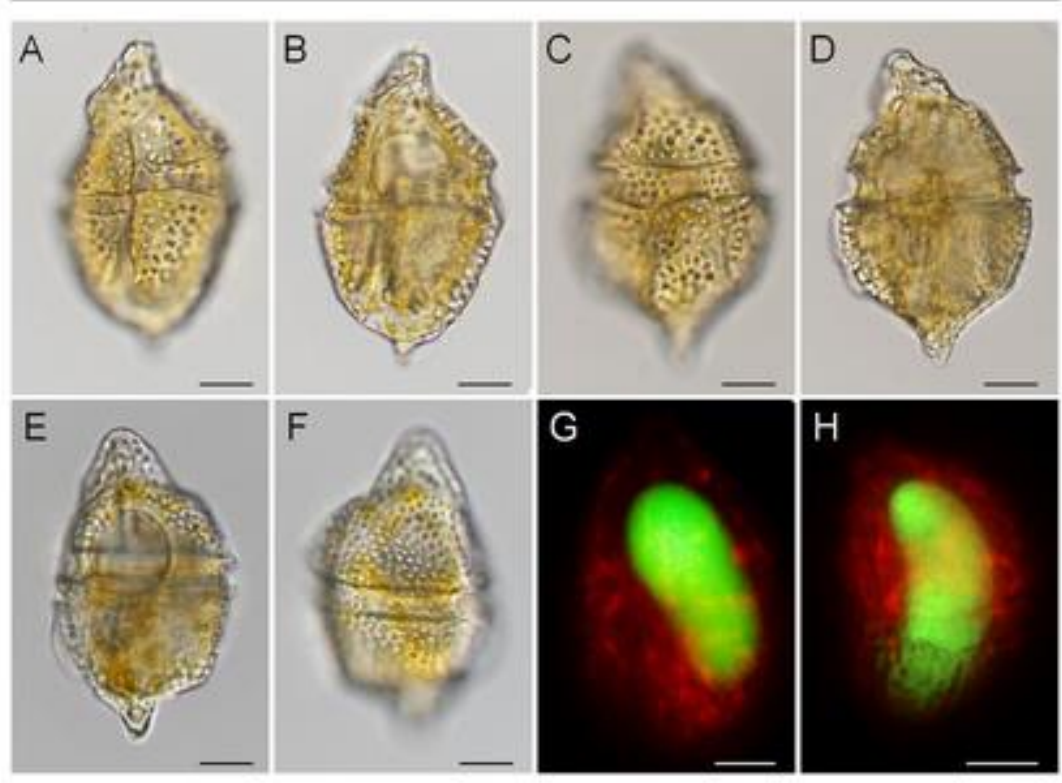

Download high-res image (841KB) Download full-size image

Fig. 1. Light and fluorescence micrographs of Centrodinium punctatum (culture strain LIMS-PS-2525). (A) Surface focus of ventral view showing the sulcus and cingulum. (B) Deeper focus of ventral view showing the outline shape and the location of the cingulum. (C) Surface focus of dorsal view showing the cingulum. (D) Deeper focus of dorsal view showing the cell shape. (E) Deeper focus of left lateral view. (F) Surface focus of right lateral view. (G) Ventral view of SYTOX Green-stained cell showing the position of the nucleus. $(\mathrm{H})$ Lateral view of SYTOX Green-stained cell showing the shape of the nucleus. Scale bars: A-H $=10 \mu \mathrm{m}$. 

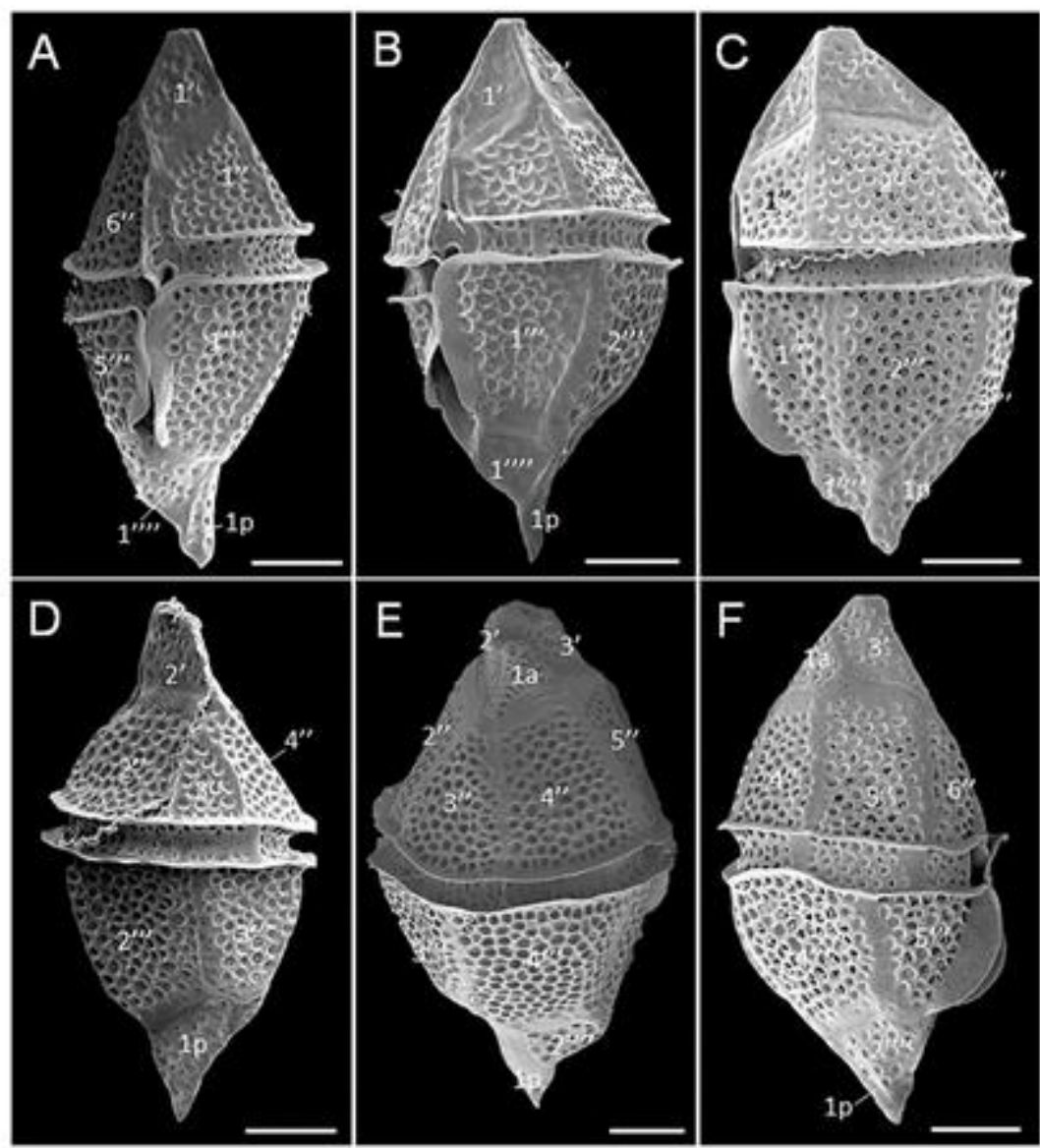

Download high-res image (1MB)

Download full-size image

Fig. 2. Scanning electron micrographs of Centrodinium punctatum. Material from culture strain LIMS-PS-2525. (A) Ventral view. (B) Ventral-left lateral view showing the ventral pore (arrow) (C) Left lateral view. (D) Dorsal view. (E) Dorsal-right lateral view (F) Right lateral view. Scale bars: $A-F=10 \mu \mathrm{m}$. 

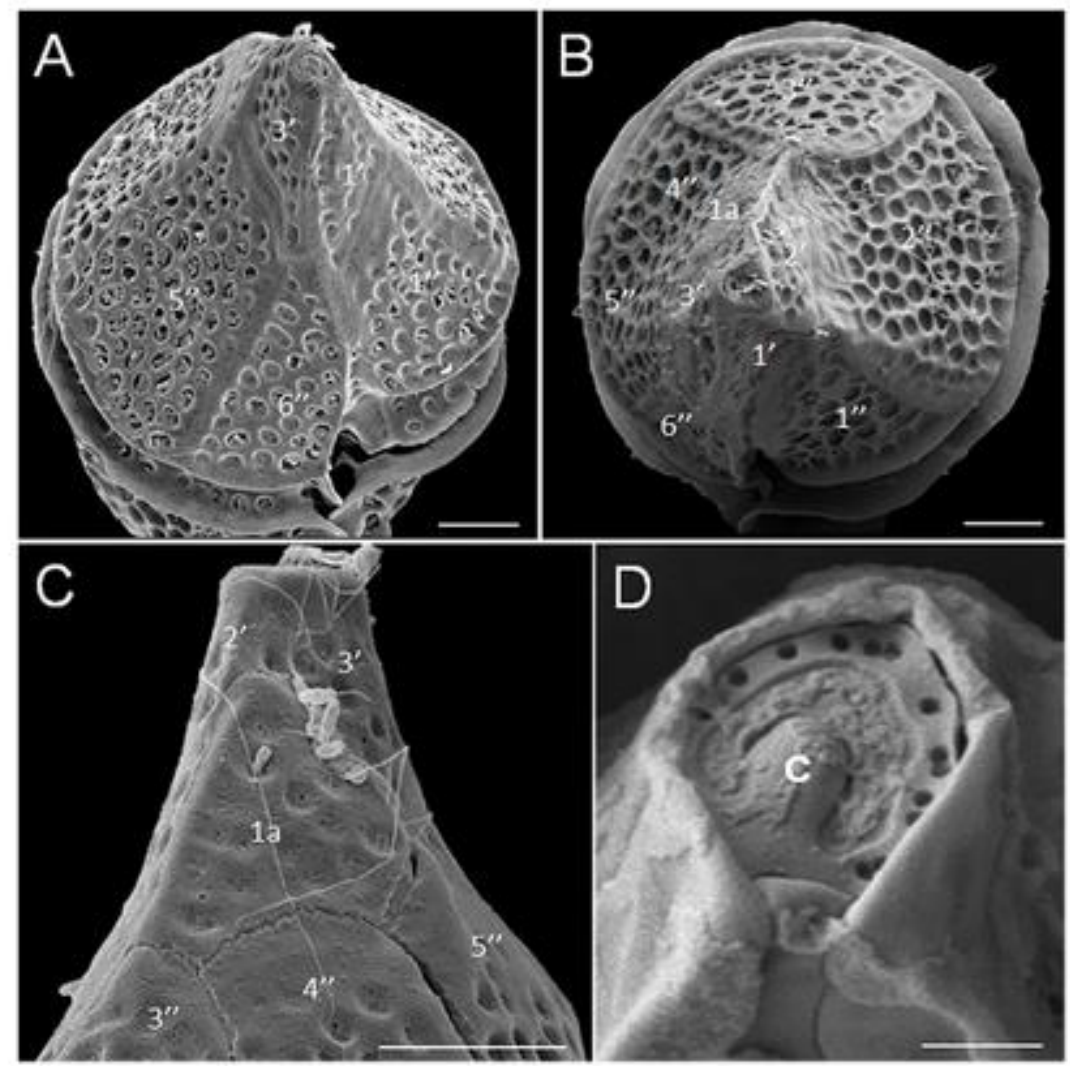

Download high-res image (934KB)

Download full-size image

Fig 3. Details of the epithecal plates of Centrodinium punctatum in scanning electron micrographs (culture strain LIMS-PS-2525). (A) Ventral view showing the shape of the first apical plate $1^{\prime}$. (B) Apical view showing the apical, anterior intercalary and precingular plates. (C) Dorsal view showing the shape of the intercalary plate 1a. (D) Apical pore plate containing a horseshoeshaped apical pore (foramen), and an elongated callus (c). Scale bars: $\mathrm{A}-\mathrm{C}=5 \mu \mathrm{m} ; \mathrm{D}=1 \mu \mathrm{m}$. 


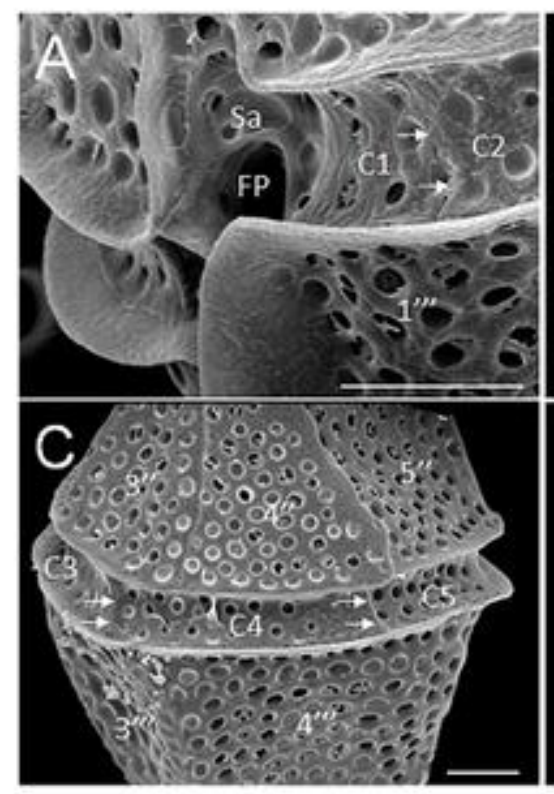

Download high-res image (867KB)

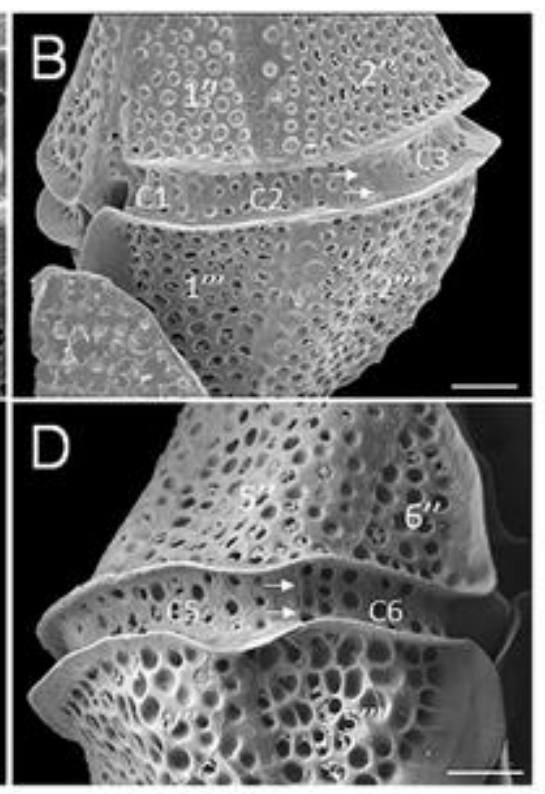

Download full-size image

Fig. 4. Details of the cingular plates of Centrodinium punctatum in scanning electron micrographs (culture strain LIMS-PS-2525). Small arrows indicate the five sutures separating the six cingular plates (C1-C6). FP: flagellar pore; Sa: anterior sulcal plate. Scale bars: $A-D=5 \mu \mathrm{m}$. 

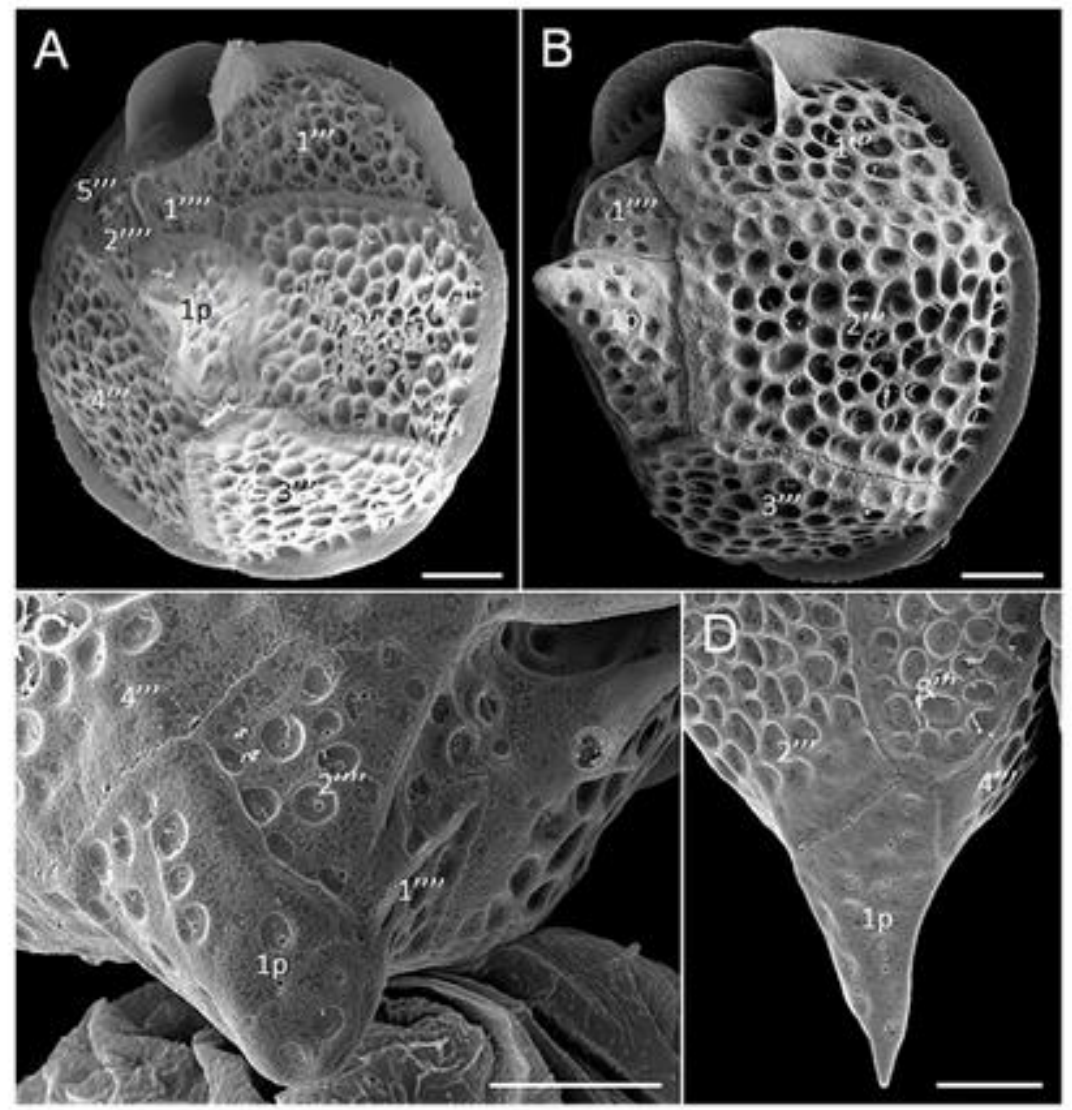

Download high-res image (1MB)

Download full-size image

Fig 5. Details of the hypothecal plates of Centrodinium punctatum in scanning electron micrographs (culture strain LIMS-PS-2525). (A-B) Antapical view showing the antapical and postcingular plates. (C-D) Details of the antapical area showing the shapes of the two antapical plates and 1p plate. Scale bars: $A-D=5 \mu \mathrm{m}$. 


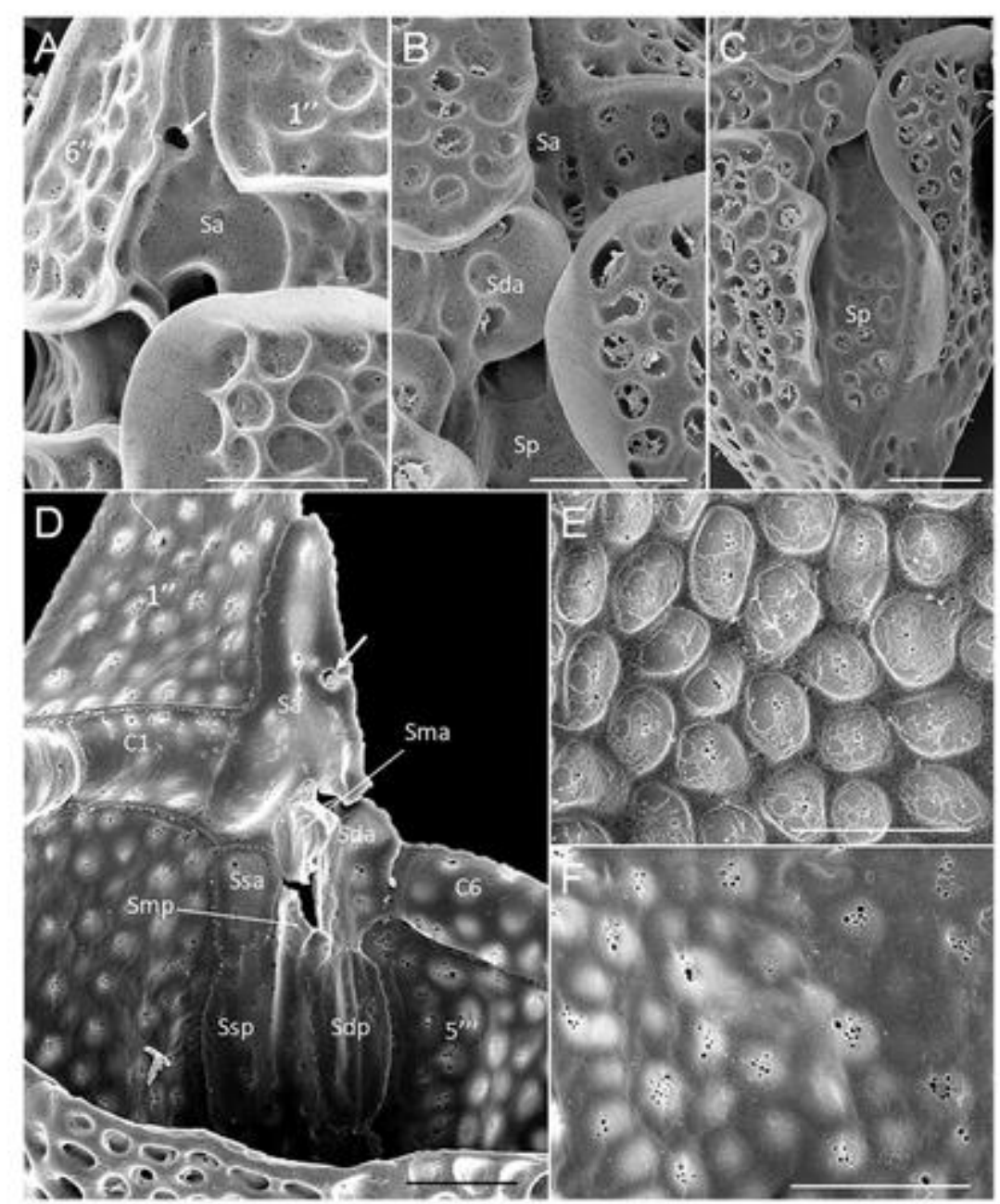

Download high-res image (2MB) Download full-size image

Fig. 6. Details of the sulcal plates and surface morphology of Centrodinium punctatum (culture strain LIMS-PS-2525) in scanning electron micrographs. (A-C) Thecal outside view of sulcal plates showing the ventral pore (arrow). (D) Thecal inside view of sulcal plates with ventral pore (arrow). (E) The areolated thecal surface with small pores at the bottom. (F) Inside view of the theca. Scale bars: $\mathrm{A}-\mathrm{F}=5 \mu \mathrm{m}$. 

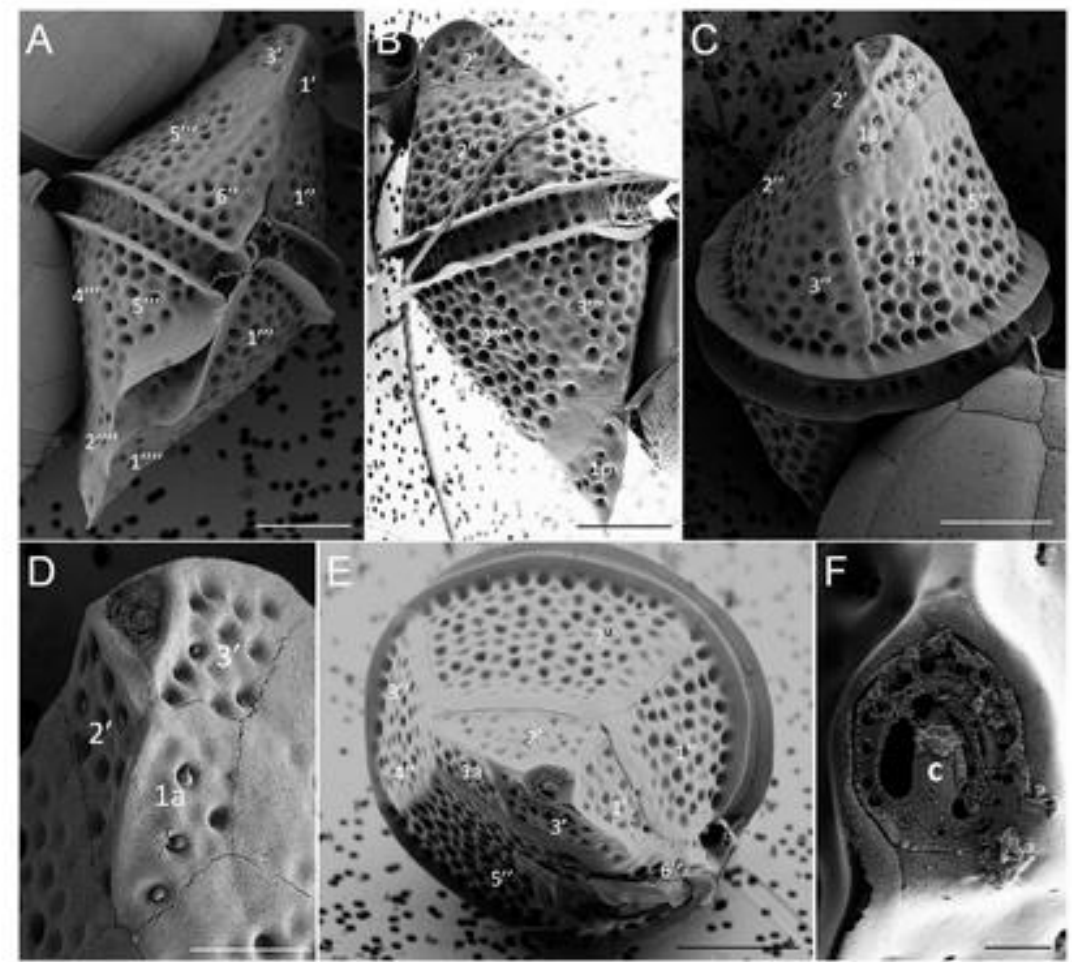

Download high-res image (2MB)

Download full-size image

Fig 7. Scanning electron micrographs of Centrodinium punctatum isolated from offshore Reunion (Indian Ocean). (A) Ventral view. (B) Dorsal view. (C-D) Details of the epithecal plates showing the position and shape of the plate 1a. (E) Apical view showing the apical and precingular plates. (F) Apical pore plate containing a horseshoe-shaped apical pore, and an elongated callus (c). Scale bars: $\mathrm{A}-\mathrm{C}=10 \mu \mathrm{m} ; \mathrm{D}=5 \mu \mathrm{m} ; \mathrm{E}=10 \mu \mathrm{m} ; \mathrm{F}=1 \mu \mathrm{m}$.
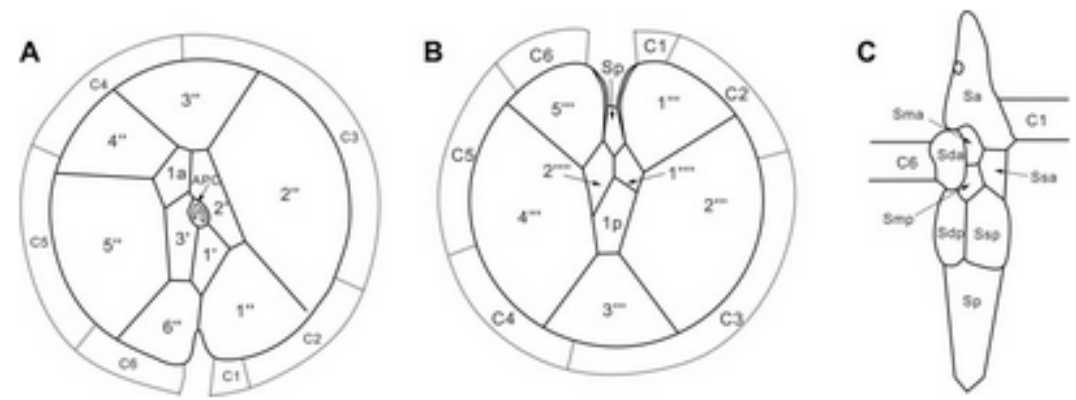

Download high-res image (287KB)

Download full-size image

Fig. 8. Diagrammatic reconstructions of Centrodinium punctatum.

(A) Apical view. (B) Antapical view. (C) Sulcal area. 


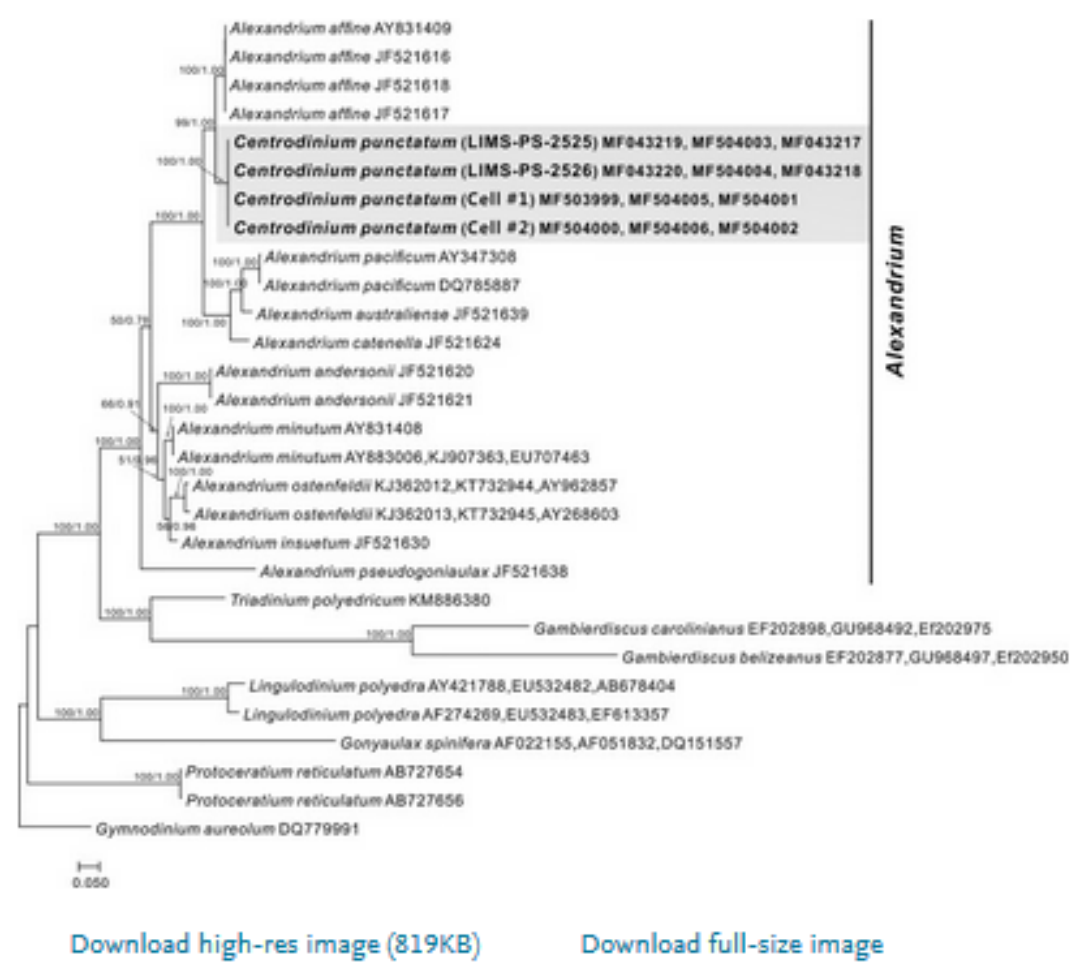

Fig 9. Maximum likelihood (ML) tree showing the phylogenetic position of Centrodinium punctatum (in bold) based on SSU+IT'S1+5.8S+IT'S2+LSU concatenated sequences (3724 bp). The unarmored dinoflagellate Gymnodinium aureolum (DQ779991) were used as the outgroup. The numbers on each node are the bootstrap values (\%) followed by the Bayesian posterior probability (PP). Only bootstrap values above $50 \%$ and PP above 0.7 are shown. The GenBank accession number follows taxon name. Scale bar $=0.05$ nucleotide substitutions per site.. 


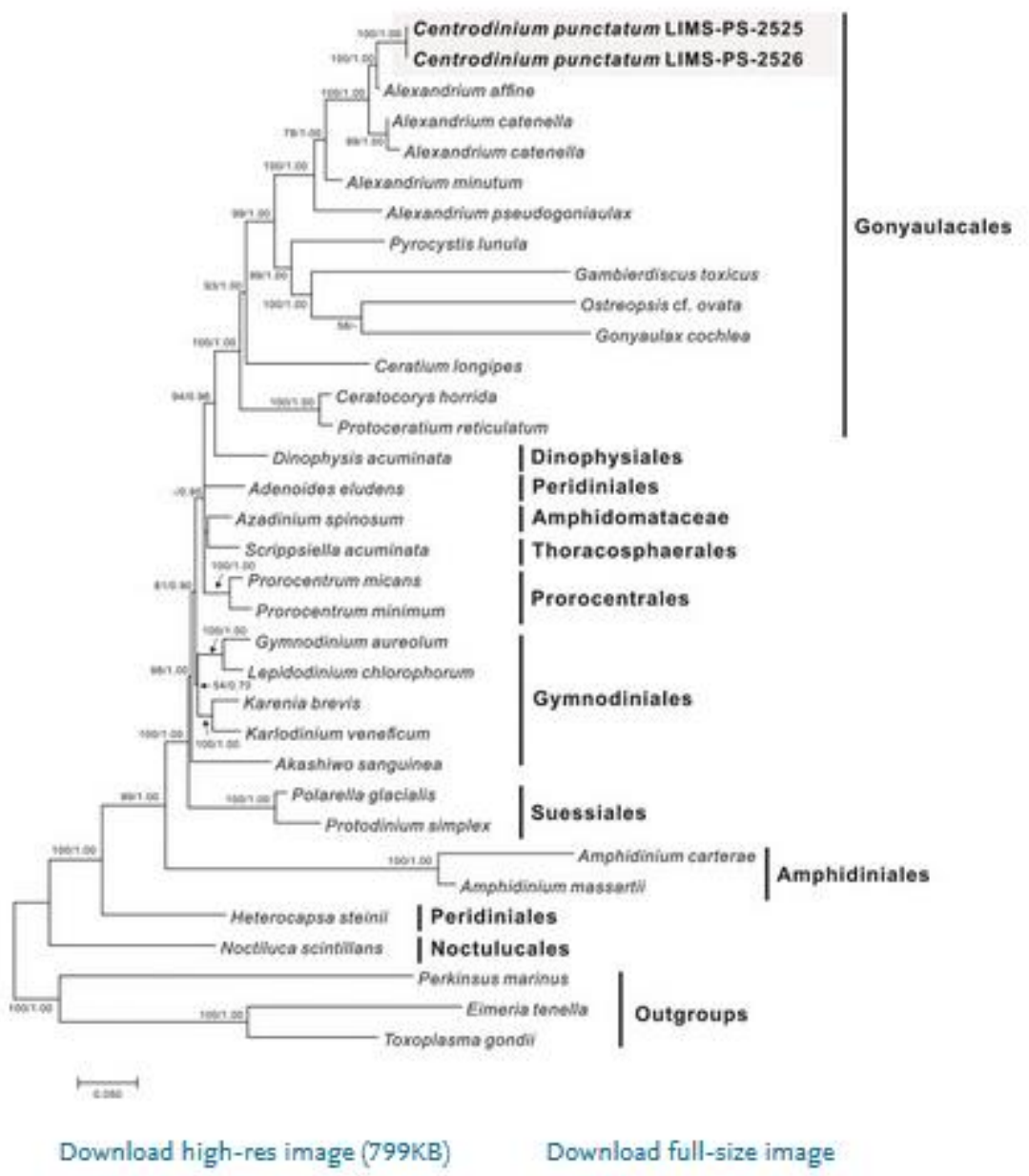

Fig. 10. Maximum likelihood (ML) tree showing the phylogenetic position of Centrodinium punctatum (in bold) based on SSUITS1-5.8S-ITS2-LSU-Cox1-Cob-Hsp90 concatenated sequences (7394bp). The sequences of the Perkinsozoan species was used as the outgroup. The numbers on each node are the bootstrap values (\%) followed by the Bayesian posterior probability (PP). Only bootstrap values above $50 \%$ and PP above 0.7 are shown. See Table S4 for a full listing of accessions used. Scale bar $=0.05$ nucleotide substitutions per site. 